\title{
Parental satisfaction with health care during child hospitalization at a social security facility in Mexico
}

\author{
Alberto Tlacuilo-Parra ${ }^{1 *}$, María R. Vizcarra-Gutiérrez², Zulema Morgan-Domínguez ${ }^{3}$, \\ Ana R. Hernández-Cervantes ${ }^{4}$, Rosa Ortega-Cortés ${ }^{1}$, and Elizabeth Guevara-Gutiérrez ${ }^{5}$
}

${ }^{1}$ Divisón de Investigación Médica, Unidad Médica de Alta Especialidad, Hospital de Pediatría, Centro Médico Nacional de Occidente, Instituto Mexicano del Seguro Social (IMSS), Guadalajara; ${ }^{2}$ Departamento de Trabajo Social, Unidad Médica de Alta Especialidad, Hospital de Pediatría, Centro Médico Nacional de Occidente, IMSS, Guadalajara; ${ }^{3}$ Departmento de Pediatría, Unidad Médica de Alta Especialidad, Hospital de Pediatría, Centro Médico Nacional de Occidente, IMSS, Guadalajara; ${ }^{4}$ Dirección Médica, Unidad Médica de Alta Especialidad, Hospital de Pediatría, Centro Médico Nacional de Occidente, IMSS, Guadalajara; ${ }^{5}$ Instituto Dermatológico de Jalisco, Secretaría de Salud Jalisco. Jalisco, Mexico

\begin{abstract}
Background: The Service Quality in Hospital (SERVQHOS) assesses quality and satisfaction with hospital care received. This study aimed to determine the quality and satisfaction of parents in a tertiary-level pediatric public facility in Mexico. Methods: We conducted a cross-sectional study in which 425 anonymous surveys were distributed during the discharge of children. The questionnaire evaluates the individual (subjective) and organizational (objective) quality of service: reliability, tangibles, assurance, responsiveness, and empathy, as well as satisfaction on a 5-point scale from 1 (much worse) to 5 (much better). Results: $A$ total of 401 questionnaires were returned (94\%). The mean quality score was $3.6 \pm 0.7$. The best-rated aspects were the medical equipment technology $(3.6+0.8)$, the confidence that the staff transmits to patients $(3.6 \pm 0.8)$, and the friendliness of the staff when attending patients $(3.6 \pm 0.8)$. The worst-rated aspects were the condition of the rooms $(3.4 \pm 0.8)$, the waiting time to be attended by a physician $(3.3 \pm 0.8)$, and the timeliness of internal consultations $(3.3 \pm 0.8)$. The overall population rated as satisfied in $97 \%$ of cases. Conclusions: A high rate of satisfaction was observed concerning both objective and subjective factors. However, the negative aspects of objective quality, such as reliability, should be addressed organizationally without implying economic investment in their resolution.
\end{abstract}

Keywords: Children. Healthcare. Quality of care. Health facility survey. Mexico. Patient satisfaction.

\section{Satisfacción de los padres con la atención médica durante la hospitalización de sus hijos en una institución de seguridad social en México}

\section{Resumen}

Introducción: La prueba de Calidad en el Servicio de Hospital (SERVQHOS) evalúa la calidad y la satisfacción con la atención hospitalaria recibida. El objetivo de este estudio fue determinar la calidad y la satisfacción de los padres de familia en un hospital público pediátrico de tercer nivel en México. Métodos: Se realizó un estudio transversal en el que se distribuyeron 425 encuestas anónimas durante el alta de los pacientes. El cuestionario evalúa la calidad individual (subjetiva) y de la organización (objetiva) del servicio: fiabilidad, tangibles, garantía, capacidad de respuesta y empatía, y satisfac-

\footnotetext{
Correspondence:

*Alberto Tlacuilo-Parra

E-mail: albtlacuilo@yahoo.com

Available online: 16-12-2021

Date of reception: 23-03-2021

Date of acceptance: 14-07-2021

DOI: 10.24875/BMHIM.21000051

Bol Med Hosp Infant Mex. 2021;78(6):549-556

www.bmhim.com

1665-1146/@ 2021 Hospital Infantil de México Federico Gómez. Published by Permanyer. This is an open access article under the CC BY-NC-ND license (http://creativecommons.org/licenses/by-nc-nd/4.0/).
} 
ción en una escala tipo Likert de 5 puntos, de 1 (mucho peor) a 5 (mucho mejor). Resultados: Se recibieron 401 encuestas respondidas (tasa de respuesta del 94\%). El 97\% de los padres calificaron la satisfacción global como satisfechos o muy satisfechos. Los aspectos mejor calificados fueron la tecnología de los equipos médicos (3.6 \pm 0.8$)$, la confianza que el personal transmite al paciente $(3.6 \pm 0.8)$ y la amabilidad del personal en su trato al paciente (3.6 \pm 0.8$)$. Los aspectos peor valorados fueron el estado de las habitaciones $(3.4 \pm 0.8)$, el tiempo de espera para ser atendido por un médico $(3.3 \pm 0.8)$ y la puntualidad de las interconsultas $(3.3 \pm 0.8)$. Conclusiones: Se observó un alto índice de satisfacción relacionado tanto con los factores objetivos como con los subjetivos. Sin embargo, los aspectos negativos de calidad objetiva, tales como la fiabilidad, deben ser atendidos por la organización sin que ello implique una inversión económica para su resolución.

Palabras clave: Niños. Cuidado de la salud. Calidad de la atención. Encuesta sobre centro de salud. Satisfacción del paciente. México.

\section{Introduction}

In western societies, the quality of public and private healthcare services is commonly evaluated by measuring user satisfaction ${ }^{1}$. The interest in seeking the opinions of users has at least a triple justification: first, from the point of view of social participation, emphasis has been placed on citizens being an integral and central part of the system, participating actively in the evaluation, planning, and redefining of healthcare policies; second, it is the users who can monitor and ultimately judge the quality of service since the subjective perception of the user speaks of the quality of the service combining their needs with their expectations ${ }^{3}$; and third, measuring satisfaction of the users is of great importance because it is proven that a satisfied patient is more disposed to following medical advice and treatment, and thus, to improve their health ${ }^{4}$.

Over 120 million Mexicans are potential users of healthcare services in one of Mexico's health subsystems. These subsystems can be classified into three groups: the social security institutions, the institutions that provide services to the population without social security, and the private sector. The formal sector workers and their families obtain healthcare services mainly through one social security entity called the Mexican Social Security Institute (IMSS, for its Spanish acronym). The IMSS is responsible for providing healthcare services to approximately 62 million potential clients, and it is financed by the earmarked employee, employer payroll taxes, and legally mandated government contributions ${ }^{5}$.

Patient satisfaction with care has been described as a multidimensional concept. Parasuraman et al. developed the Service Quality Questionnaire (SERVQUAL) for its use by service and retail organizations. According to these authors, there are five dimensions to service quality: reliability (the ability to carry out the promised service reliably and accurately), tangibles (equipment, physical facilities, and staff appearance), assurance (employee courtesy and knowledge, and their ability to inspire confidence and trust), responsiveness (the effort to help customers and provide fast service), and empathy (individualized attention the firm provides its clients) ${ }^{6}$. Although SERVQUAL was initially designed for application within financial service areas, the model is intended for a wide range of services, and its potential usefulness in a hospital environment has been evaluated and proven ${ }^{7,8}$. By using SERVQUAL as a guide, the Service Quality in Hospital Questionnaire (SERVQHOS) was developed for its use in the healthcare sector in Spanish-speaking countries ${ }^{9}$. We have chosen SERVQHOS as the measurement tool for assessing satisfaction because it is a brief questionnaire that is easy to complete, and it is broadly used in Spanish-speaking countries as a validated questionnaire ${ }^{10}$. This study aimed to describe parental satisfaction with healthcare during their child's hospitalization in a pediatric social security facility in Mexico.

\section{Methods}

\section{Study population}

This cross-sectional study consisted of parents of pediatric patients hospitalized in an academic, tertiary care pediatric medical facility in western Mexico. The facility offers care for children < 16 years of age. In 2018 , the capacity of the pediatric and surgical wards was 250 beds, with 8,834 admissions, 3,979 surgical procedures, and 92,847 outpatient visits. The questionnaire was given between February and May 2019 to all parents who consented to participate and could read and write in Spanish.

\section{Measurements}

The SERVQHOS questionnaire is divided into three sections. The first section included 19 items measuring 
perception of several factors that influence the quality of assistance rated on a 5-point Likert scale, where 1 $=$ much worse than expected; 2 = worse than expected; $3=$ as expected; $4=$ better than expected; $5=$ much better than expected. Patients had to answer the question, "How did you find the quality of assistance on the following aspects?", rating from 1 to 5 . The 19 aspects included the five dimensions of service quality: reliability, tangibles, assurance, responsiveness, and empathy. The items could also be divided into subjective quality (human assistance) and objective quality (organizational and facility issues) ${ }^{9}$.

The second section included questions regarding overall satisfaction (rated on a 4-point Likert scale, where 1 = very dissatisfied, 2 = dissatisfied, $3=$ satisfied, and $4=$ very satisfied). For example, if the length of stay was appropriate, if they would recommend the hospital, if the hospitalization was scheduled or urgent, the number of hospital admissions in the last year, whether the information received was adequate, and whether they knew the name of the doctors and nurses.

The third section included socio-demographic data like sex, age, marital status, educational level, and employment status. In the end, free space was provided for feedback. The SERVQHOS is a generic, non-surgery-specific questionnaire. The instrument showed a Cronbach's alpha for the domains ranging

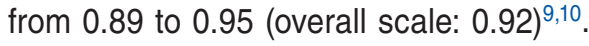

\section{Procedure}

The questionnaires were delivered to the parents during child discharge. A trained social worker informed the parents about the purpose and the importance of their participation and gave an informed consent form to be signed. The questionnaire was provided with a blank envelope. Parents answered the questionnaire, placed it inside the envelope, and sealed it. The time to complete the questionnaire was 10 minutes. The social worker was available for clarifications as needed while parents responded to the questionnaire. One member of the team collected the sealed envelopes daily. Neither the questionnaire nor the envelope contained any questions or distinguishing signs leading to the identification of the participants. Regardless, the anonymity of the participants was ensured. No material or financial compensation was provided to participants. The local Research and Ethics Committee of the Mexican Social Security Institute approved the study protocol (CLIS R-2019-1302-011).

\section{Statistical analysis}

A pre-analysis power calculation gave the study > $84 \%$ power, $\alpha=0.05$, with a sample size of 425 . Initially, 425 questionnaires were delivered, but parent surveys with more than $50 \%$ of unanswered questions were excluded from the analysis, which occurred in $24(5.6 \%)$ of the surveys. Data were presented as mean \pm standard deviation (SD), median, or percentages as appropriate. We performed logistic regression analyses in those factors statistically associated with overall satisfaction when comparing the very satisfied group vs. the other categories, including marital status (having a couple vs. not having a couple), level of education (secondary education or less), scheduled hospital admission, and have received enough information about child health status. The standardized regression coefficient and $\mathrm{R}^{2}$ determination coefficients were calculated. Data were analyzed with the SPSS Statistical Software Package (version 20.0 for Windows; SPSS, Inc., Chicago, IL). A value of $p<0.05$ was considered statistically significant.

\section{Results}

\section{Demographics and quality evaluation}

The population consisted of 401 parents (401 pediatric patients). The parents' mean age was $33 \pm 8$ years old, most of the participants were women 302 (75\%), $322(80 \%)$ had a couple (including married and common law), $218(54 \%)$ completed at least secondary school education, and 204 (50\%) were homemakers. The demographic characteristics of the parents are summarized in Table 1.

The results of the quality first section of the SERVQHOS questionnaire are presented as a mean and SD of a 5-point Likert scale rate (Table 2). Among the best-rated aspects were those related to objective quality (tangibles dimension): modern equipment technology, $3.68 \pm 0.86$; hospital employee appearance, $3.65 \pm 0.84$; and subjective quality (assurance dimension), including the ability to inspire trust and confidence (3.66 \pm 0.83$)$, employee courtesy $(3.65 \pm 0.83)$, and nursing staff interest in patients $(3.65 \pm 0.85)$. However, the aspects that users rated worst were those related to objective quality (reliability dimension): waiting time for services $(3.37 \pm 0.82)$ and timeliness at the doctor's visit ( $3.34 \pm 0.80$ ), as well as (tangibles dimension) room conditions $(3.46 \pm 0.82)$ and ease of getting to the hospital $(3.40 \pm 0.85)$. 
Table 1. Demographic characteristics of responders

\begin{tabular}{|c|c|c|c|c|}
\hline \multirow[t]{3}{*}{ Total population } & & \multicolumn{2}{|c|}{ Comparison between groups } & \multirow[t]{3}{*}{$p$-values } \\
\hline & & Very satisfied & Others & \\
\hline & $n=401(\%)$ & $\mathrm{n}=78(\%)$ & $n=323(\%)$ & \\
\hline $\begin{array}{l}\text { Age } \\
\qquad \text { Mean } \pm \text { SD }\end{array}$ & $33 \pm 8$ & $33 \pm 8$ & $34 \pm 8$ & 0.34 \\
\hline $\begin{array}{l}\text { Sex } \\
\text { Female } \\
\text { Male } \\
\text { Not available }\end{array}$ & $\begin{array}{l}302(75) \\
97(24) \\
2(0.5)\end{array}$ & $\begin{array}{l}55(70) \\
22(28) \\
1(1.2)\end{array}$ & $\begin{array}{c}247(76) \\
75(23) \\
1(0.3)\end{array}$ & 0.344 \\
\hline $\begin{array}{l}\text { Marital status } \\
\text { Having couple } \\
\text { Not having couple } \\
\text { Not available }\end{array}$ & $\begin{array}{c}322(80.2) \\
75(18.7) \\
4(0.9)\end{array}$ & $\begin{array}{c}55(70.5) \\
20(25.6) \\
3(3.8)\end{array}$ & $\begin{array}{c}267(82.6) \\
55(17.0) \\
1(0.3)\end{array}$ & 0.056 \\
\hline $\begin{array}{l}\text { Education level } \\
\text { Secondary or less } \\
\text { Preparatory or higher } \\
\text { Not available }\end{array}$ & $\begin{array}{c}218(54.3) \\
181(45.1) \\
2(0.4)\end{array}$ & $\begin{array}{c}52(66.6) \\
25(32.0) \\
1(1.2)\end{array}$ & $\begin{array}{c}166(51.3) \\
156(48.2) \\
1(0.3)\end{array}$ & 0.016 \\
\hline $\begin{array}{l}\text { Occupation } \\
\text { Homemaker } \\
\text { Student } \\
\text { Employed } \\
\text { Retired } \\
\text { Not available }\end{array}$ & $\begin{array}{c}204(50.8) \\
6(1.4) \\
187(46.6) \\
2(0.4) \\
2(0.4)\end{array}$ & $\begin{aligned} 42 & (53) \\
2 & (2) \\
33 & (42) \\
0 & (0) \\
1 & (1)\end{aligned}$ & $\begin{array}{c}162(50) \\
4(1) \\
154(47) \\
2(0.6) \\
1(0.3)\end{array}$ & 0.563 \\
\hline
\end{tabular}

SD, standard deviation.

\section{Satisfaction evaluation}

The results of the satisfaction second section of the questionnaire are shown in Table 3. The overall satisfaction with care was rated on a 4-point Likert scale as follows: very dissatisfied $(0 \%), 8$ dissatisfied $(1.9 \%), 315$ satisfied $(78.5 \%)$, and 78 very satisfied parents (19.4\%); additionally, 388 parents (96\%) would not hesitate to recommend the hospital to others. Also, 382 parents (95\%) believed that their child stayed in the hospital necessary length of time, and 394 parents (98\%) responded that their child did not undergo medical tests without permission. However, 39 parents (9\%) did not know the name of the doctor who treated their child during hospitalization, and 29 parents $(7 \%)$ did not know the nurse's name. The free space for feedback was used by 96 parents $(23.9 \%)$ who gave one or more comments or suggestions: 27 acknowledgments/words of gratitude (28\%), and $69 \mathrm{com}$ plaints $(72 \%)$ about the facilities, catering services, the care received by staff, and the lack of personnel.

\section{Comparisons between groups}

To know which factors determined satisfaction in our population, we grouped the parents into two groups: those who rated the attention as 'very satisfied' $78(19.4 \%)$ and those who rated the rest of the categories as dissatisfied and satisfied $323(80.5 \%)$. We did not observe any significant differences in age, sex, and occupation upon comparing the demographic characteristics. In contrast, we observed a tendency concerning having a couple or not (including married and common law) ( $p=0.056)$ and a statistically significant difference regarding the level of education (secondary education or less) $(p=0.016)$ (Table 1). When comparing the first section of the SERVQHOS questionnaire results between the very satisfied group and the rest of the categories, we observed statistically significant differences ( $p=0.001$ ) in the 19 questions of that section. Conversely, for the seven questions that comprise the second section of the questionnaire, we only observed a significant difference for the question "Did you get enough information?" ( $p=0.001$ ) (Table 3 ).

With this information, we performed a multiple logistic regression analysis, considering the level of satisfaction of 'very satisfied' as a dependent variable and the variables that were found to be significant in the bivariate analysis as predictors: not having a couple ( $p=0.056)$, secondary level of education or less $(p=0.016)$, having received enough information 
Table 2. SERVOHOS (Service Quality in Hospital) parental quality evaluation with care-Part 1

\begin{tabular}{|c|c|c|c|c|}
\hline \multirow[t]{2}{*}{ Evaluation } & \multirow{2}{*}{$\begin{array}{c}\text { Score } \\
\text { Mean } \pm \text { SD }\end{array}$} & \multicolumn{2}{|c|}{ Much worse/Worse } & \multirow{2}{*}{$\begin{array}{c}\text { Much better/Better } \\
\mathbf{n}(\%)\end{array}$} \\
\hline & & n (\%) & n (\%) & \\
\hline Total satisfaction with care & $3.63 \pm 0.79$ & $6(1.4)$ & 208 (51.8) & $187(46.6)$ \\
\hline \multicolumn{5}{|c|}{ Objective quality } \\
\hline $\begin{array}{l}\text { Tangibles } \\
\text { Modern equipment technology } \\
\text { Hospital employee appearance } \\
\text { Location directions } \\
\text { Room conditions } \\
\text { Ease of getting to the hospital }\end{array}$ & $\begin{array}{l}3.68 \pm 0.86 \\
3.65 \pm 0.84 \\
3.54 \pm 0.81 \\
3.46 \pm 0.82 \\
3.40 \pm 0.85\end{array}$ & $\begin{array}{l}6(1.4) \\
7(1.7) \\
11(2.7) \\
20(4.9) \\
26(6.4)\end{array}$ & $\begin{array}{l}209(52.1) \\
213(53.1) \\
227(56.6) \\
223(55.6) \\
229(57.1)\end{array}$ & $\begin{array}{l}186(46.3) \\
181(45.1) \\
163(40.6) \\
158(39.4) \\
146(36.4)\end{array}$ \\
\hline $\begin{array}{l}\text { Reliability } \\
\text { Accomplishment of promised services } \\
\text { Waiting time for service } \\
\text { Timeliness of doctor's visit }\end{array}$ & $\begin{array}{l}3.59 \pm 0.81 \\
3.37 \pm 0.82 \\
3.34 \pm 0.80\end{array}$ & $\begin{array}{l}10(2.4) \\
28(6.9) \\
34(8.4)\end{array}$ & $\begin{array}{l}215(53.6) \\
238(59.3) \\
231(57.6)\end{array}$ & $\begin{array}{l}176(43.8) \\
135(33.6) \\
136(33.9)\end{array}$ \\
\hline \multicolumn{5}{|c|}{ Subjective quality } \\
\hline $\begin{array}{l}\text { Responsiveness } \\
\text { Sincere interest in solving problems } \\
\text { Provision of prompt services } \\
\text { Willingness to help patients }\end{array}$ & $\begin{array}{l}3.55 \pm 0.80 \\
3.47 \pm 0.78 \\
3.62 \pm 0.84\end{array}$ & $\begin{array}{l}12(2.9) \\
19(4.7) \\
11(2.7)\end{array}$ & $\begin{array}{l}218(54.3) \\
226(56.3) \\
209(52.1)\end{array}$ & $\begin{array}{l}171(42.6) \\
156(38.9) \\
181(45.1)\end{array}$ \\
\hline $\begin{array}{l}\text { Assurance } \\
\text { Ability to inspire trust and confidence } \\
\text { Employee courtesy } \\
\text { Employees professional skills } \\
\text { Nursing staff interest in patients }\end{array}$ & $\begin{array}{l}3.66 \pm 0.83 \\
3.65 \pm 0.83 \\
3.62 \pm 0.82 \\
3.65 \pm 0.85\end{array}$ & $\begin{array}{l}9(2.2) \\
5(1.2) \\
9(2.2) \\
6(1.4)\end{array}$ & $\begin{array}{l}200(49.8) \\
212(52.8) \\
212(52.8) \\
215(53.6)\end{array}$ & $\begin{array}{l}192(47.8) \\
184(45.8) \\
180(44.8) \\
180(44.8)\end{array}$ \\
\hline $\begin{array}{l}\text { Empathy } \\
\text { Individual personal attention } \\
\text { Understanding of specific patients' needs }\end{array}$ & $\begin{array}{l}3.62 \pm 0.83 \\
3.56 \pm 0.79\end{array}$ & $\begin{array}{l}9(2.2) \\
8(1.9)\end{array}$ & $\begin{array}{l}213(53.1) \\
225(56.1)\end{array}$ & $\begin{array}{l}179(44.6) \\
168(41.8)\end{array}$ \\
\hline \multicolumn{5}{|c|}{ Objective quality } \\
\hline $\begin{array}{l}\text { Others } \\
\text { Information about treatments } \\
\text { Information to relatives/families }\end{array}$ & $\begin{array}{l}3.58 \pm 0.86 \\
3.56 \pm 0.84\end{array}$ & $\begin{array}{l}18(4.4) \\
15(3.7)\end{array}$ & $\begin{array}{l}208(51.8) \\
220(54.8)\end{array}$ & $\begin{array}{l}175(43.6) \\
166(41.3\end{array}$ \\
\hline
\end{tabular}

SD, standard deviation.

$(p=0.001)$, and type of hospital admission $(p=0.056)$. This model achieved an explanatory power on the variable 'very satisfied' from $53 \%$ to $83 \%$ (R squared of Cox and Snell: 0.52; and $R$ squared of Nagelkerke: 0.83 , respectively); however, the variables not having a couple and secondary level of education or less were not statistically significant in this model (Table 4).

\section{Discussion}

The Mexican health care system seems to be overstretched, and healthcare quality has remained unsatisfactory for most of the population. A 2006 national survey found substantial heterogeneity in healthcare quality assessments across healthcare subsystems, favoring private providers over social security institutions.
Moreover, $76 \%$ of Mexicans thought their health system needed fundamental changes ${ }^{11}$. As a result of the healthcare system overhaul, the quality of care has become increasingly important. Furthermore, experts emphasize that the results of patient satisfaction questionnaires will be required by insurance companies and care providers ${ }^{12-14}$.

Methods that measure patient satisfaction are not well applied in specific populations like children, who have difficulties expressing their views directly ${ }^{15}$. In contrast, a quality assessment of parental satisfaction with service provision is particularly challenging and rarely undertaken ${ }^{16}$. Parental satisfaction has been used successfully to measure quality for pediatric patients' attention as it is closely linked to the adequacy of children's treatment and staff performance in pediatric practice ${ }^{17}$. A thorough review of the literature 
Table 3. SERVOHOS (Service Quality in Hospital) parental satisfaction evaluation with care-Part 2

\begin{tabular}{|c|c|c|c|c|}
\hline \multirow[t]{3}{*}{ Total population } & & \multicolumn{2}{|c|}{ Comparison between groups } & \multirow[t]{3}{*}{$p$-values } \\
\hline & & Very satisfied & Others & \\
\hline & $n=401(\%)$ & $n=78(\%)$ & $n=323(\%)$ & \\
\hline $\begin{array}{l}\text { Would you recommend this hospital? } \\
\text { Yes, no doubt } \\
\text { I am not sure } \\
\text { Never } \\
\text { Information unavailable }\end{array}$ & $\begin{array}{c}388(96.4) \\
12(3.2) \\
0(0) \\
1(0.2)\end{array}$ & $\begin{array}{c}78(100) \\
0(0) \\
0(0) \\
0(0)\end{array}$ & $\begin{array}{l}310(96) \\
12(3) \\
0(0) \\
1(0.3)\end{array}$ & 0.197 \\
\hline $\begin{array}{l}\text { Your patient underwent a medical test without your } \\
\text { permission? } \\
\text { No } \\
\text { Yes } \\
\text { Information unavailable }\end{array}$ & $\begin{array}{c}394(98.2) \\
6(1.4) \\
1(0.2)\end{array}$ & $\begin{array}{c}78(100) \\
0(0) \\
0(0)\end{array}$ & $\begin{array}{c}316(98) \\
6(1) \\
1(0.3)\end{array}$ & 0.423 \\
\hline $\begin{array}{l}\text { Do you believe the length of stay of your child was } \\
\text { Shorter than necessary } \\
\text { Adequate } \\
\text { Longer than necessary } \\
\text { Information unavailable }\end{array}$ & $\begin{array}{c}5(1.2) \\
382(95.2) \\
13(3.2) \\
1(0.2)\end{array}$ & $\begin{aligned} 2 & (2) \\
75 & (96) \\
1 & (1) \\
0 & (0)\end{aligned}$ & $\begin{array}{c}3(0.9) \\
307(95) \\
12(3) \\
1(0.3)\end{array}$ & 0.432 \\
\hline $\begin{array}{l}\text { Do you know your doctor's name? } \\
\text { Yes } \\
\text { No } \\
\text { Information unavailable }\end{array}$ & $\begin{array}{c}361(90) \\
39(9.7) \\
1(0.2)\end{array}$ & $\begin{array}{c}69(88) \\
9(11) \\
0(0)\end{array}$ & $\begin{array}{c}292(90) \\
30(9) \\
1(0.3)\end{array}$ & 0.742 \\
\hline $\begin{array}{l}\text { Do you know your nurse's name? } \\
\text { Yes } \\
\text { No } \\
\text { Information unavailable }\end{array}$ & $\begin{array}{l}371(92.5) \\
29(7.2) \\
1(0.2)\end{array}$ & $\begin{array}{c}70 \text { (89) } \\
7(8) \\
1(1)\end{array}$ & $\begin{array}{c}301(93) \\
22(6) \\
0(0)\end{array}$ & 0.098 \\
\hline $\begin{array}{l}\text { Do you get enough information? } \\
\text { Yes } \\
\text { No } \\
\text { Information unavailable }\end{array}$ & $\begin{array}{c}347(86.5) \\
53(13.2) \\
1(0.2)\end{array}$ & $\begin{array}{l}75(96) \\
2(2) \\
1(1)\end{array}$ & $\begin{array}{l}272(84) \\
51(15) \\
0(0)\end{array}$ & 0.001 \\
\hline $\begin{array}{l}\text { Hospital admission } \\
\text { Emergency } \\
\text { Scheduled } \\
\text { Information unavailable }\end{array}$ & $\begin{array}{c}222(55.3) \\
173(43.1) \\
6(1.4)\end{array}$ & $\begin{array}{l}34(43) \\
42(53) \\
2(2)\end{array}$ & $\begin{array}{c}188(58) \\
131(40) \\
4(1)\end{array}$ & 0.056 \\
\hline $\begin{array}{l}\text { Number of admissions during the last year } \\
\text { Mean }\end{array}$ & $1.9 \pm 2.7$ & $1.7 \pm 1.3$ & $2.1 \pm 2.5$ & 0.055 \\
\hline $\begin{array}{l}\text { Hospitalization service evaluated } \\
\text { Cardiac surgery } \\
\text { Cardiology } \\
\text { Maxillofacial surgery } \\
\text { Pediatric surgery } \\
\text { Plastic surgery } \\
\text { Endocrinology } \\
\text { Gastroenterology } \\
\text { Hematology } \\
\text { Infectology } \\
\text { Internal medicine } \\
\text { Nephrology } \\
\text { Neonatology } \\
\text { Respirology } \\
\text { Neurosurgery } \\
\text { Neurology } \\
\text { Oncology } \\
\text { Otorhinolaryngology } \\
\text { Orthopedics } \\
\text { Pediatrics } \\
\text { Rheumatology } \\
\text { Emergency } \\
\text { Urology } \\
\text { Information unavailable }\end{array}$ & $\begin{array}{c}4(0.99) \\
58(14.4) \\
1(0.2) \\
36(8.9) \\
9(2.2) \\
5(1.2) \\
23(5.7) \\
32(7.9) \\
3(0.7) \\
6(1.4) \\
8(1.9) \\
7(1.7) \\
11(2.7) \\
10(2.4) \\
35(8.7) \\
28(7.2) \\
3(0.7) \\
6(1.4) \\
17(4.2) \\
3(0.7) \\
48(11.7) \\
13(3.2) \\
35(8.7)\end{array}$ & $\begin{array}{c}0(0) \\
7(12) \\
0(0) \\
4(11) \\
3(33) \\
0(0) \\
5(22) \\
6(19) \\
0(0) \\
2(33) \\
1(12) \\
1(14) \\
2(18) \\
0(0) \\
3(8) \\
2(7) \\
1(33) \\
2(33) \\
7(41) \\
2(67) \\
15(31) \\
5(38) \\
10(29)\end{array}$ & $\begin{array}{c}4(100) \\
51(88) \\
1(100) \\
32(89) \\
6(67) \\
5(100) \\
18(78) \\
26(81) \\
3(100) \\
4(67) \\
7(88) \\
6(86) \\
9(82) \\
10(100) \\
32(92) \\
26(93) \\
2(67) \\
4(67) \\
10(59) \\
1(33) \\
33(69) \\
8(62) \\
25(71)\end{array}$ & \\
\hline
\end{tabular}


Table 4. Parents' satisfaction with healthcare-logistic regression

\begin{tabular}{|l|c|c|c|c|}
\hline Variable & $p$-values & $\beta$ coefficient & \multicolumn{2}{|c|}{ Confidence interval $95 \%$} \\
\cline { 3 - 5 } & & & Lower & Upper \\
\hline Enough information received & & & 0.035 & 0.626 \\
\hline Scheduled hospital admission & 0.009 & 0.149 & 0.314 & 0.882 \\
\hline Secondary educational level or less & 0.015 & 0.526 & 0.263 & 1.155 \\
\hline Not having a couple & 0.115 & 0.552 & 0.815 & 2.390 \\
\hline
\end{tabular}

revealed a lack of studies that have examined a broader perspective of parents' views on the quality of pediatric ward healthcare. Previous studies have been focused on specific areas such as emergency care $^{18}$, intensive pediatric care $^{19}$, neonatal intensive care ${ }^{20}$, and pain management ${ }^{21}$ or parental involvement in the care of their child ${ }^{22}$.

This study analyzed the perceived parental quality and satisfaction with healthcare in tertiary care, social security, pediatric facility. We achieved a participation rate of $94 \%$ in our study, which is quite similar to the Arrebola-Pajares et al. study in Spain, with a participation rate of $92 \%$ using the same SERVQHOS questionnaire but in adult patients with urological conditions ${ }^{23}$. In our unit, the quality issues rated worst by parents were aspects concerning objective quality (waiting time for service, punctuality of doctor's visit, room conditions, and ease of getting to the hospital); this situation has also been highlighted in other surveys using SERVQHOS 23,24 . The best-rated aspects were objective quality (modern equipment technology) and subjective quality (ability to inspire trust and confidence, employee courtesy, and nursing staff interest in patients). Similar results but higher mean scores were reported in the study of Gomez et al. applied to adult patients from a burn unit in Spain ${ }^{24}$. Our results demonstrate a high level of overall parental satisfaction: $78 \%$ satisfied and $19 \%$ very satisfied, while dissatisfaction rated as 'not very satisfied' was only $2 \%$, similar to that published by Perez et al., where they referred to dissatisfaction ranging from $2.9 \%$ to $2.5 \%$ when comparing a public healthcare center vs. a private institution ${ }^{25}$. To the best of our knowledge, this is the first time the SERVQHOS questionnaire has been applied to parents of pediatric patients. Therefore, we cannot make specific comparisons at this time, unfortunately.

Few of the parents did not know the name of the doctor who attended their child $(9 \%)$, while the name of the nurse was unknown to a slightly lower percentage $(7 \%)$. This lack of awareness could be caused by staff rotations: a high percentage of its eventuality occurs in our facility, which did not allow identification of a nurse as a point of reference. Knowing the name of the person who provides services improves the achievement of treatment in patients. Our results are better than those published by other authors, where the percentages varied from $20 \%$ to $40 \%$. However, this aspect should be improved ${ }^{24,25}$. Regarding the number of previous hospitalizations, our results are consistent with the study performed by Ygge et al., where parents whose child was hospitalized several times in the past expressed lower levels of satisfaction ${ }^{26}$.

In the logistic regression analysis, we observed that the variables of having received enough information and pre-scheduled hospitalization were the most influencing factors on the overall satisfaction in parents, achieving an explanatory power from $52 \%$ al $83 \%$. In contrast to other studies, we did not observe a significant difference in marital status variables and level of education ${ }^{27}$. In the present study, the questions regarding treatments and information to relatives/families were scored low (3.58 and 3.56 points, respectively). Moreover, $13 \%$ of the parents referred not having received enough information, a result lower than Tolosa et al. study in a public hospital in Colombia, where $31 \%$ of parents referred dissatisfied with the information provided 28 .

In the free space for feedback, the parents mainly complained about not having enough information about the illness, the resolution of doubts in an everyday language, and uncertainty about the outcome of the illness and the evolution of the patient. These grievances fit into the three domains proposed in the taxonomy of Reader et al. ${ }^{29}$, in which communication is a common complaint issue. This finding agrees with previous publications that report significant problems in staff-patient relationships and communication between staff and patients ${ }^{30}$. 
The limitations of our study include that it was conducted at a single-center tertiary level facility, which limits the generalizability since the experiences of parents of children admitted in other contexts may vary. The use of questionnaires to evaluate the level of satisfaction is a simple and effective tool, but it depends on the expectations of the parents: if parental expectations are low, their perceptions of the quality received will be better. Although the hospital from which the sample was drawn is the most extensive pediatric facility in the northwest of Mexico, the results should be interpreted with caution because it is unclear how these findings represent parental satisfaction in other pediatric wards of the IMSS healthcare network.

\section{Ethical disclosures}

Protection of human and animal subjects. The authors declare that no experiments were performed on humans or animals for this study.

Confidentiality of data. The authors declare that they have followed the protocols of their work center on the publication of patient data.

Right to privacy and informed consent. The authors have obtained the written informed consent of the patients or subjects mentioned in the article. The corresponding author has this document.

\section{Conflicts of interest}

The authors declare no conflict of interest.

\section{Funding}

None.

\section{References}

1. Clearly PD, Edgman-Levitan S, Roberts M, Moloney TW, McMullen W, Walker JD, et al. Patients evaluate their hospital care: a national survey. Health Aff (Millwood). 1991;10:254-67.

2. Ruíz de Chávez M, Martínez-Narváez G, Calvo-Ríos JM, Aguirre-Gas H, Arango-Rojas R, Lara-Carreño $\mathrm{R}$, et al. [Basis for the evaluation of health care quality at the medical units of the health sector]. Salud Publica Mex. 1990;32:159-69.

3. Donabedian A. [Continuity and change in the search for quality]. Salud Publica Mex. 1993:35:238-47.

4. Otani K, Waterman B, Faulkner KM, Boslaugh S, Burroughs TE, Dunagan WC. Patient satisfaction: focusing on "excellent." J Healthc Manag. 2009;54:93-102.
5. Gómez-Dantés O, Frenk J. [Chronicle of a century of public health in Mexico: from public health to social protection in health]. Salud Publica Mex. 2019;61:202-11.

6. Parasuraman A, Zeithaml V, Berry L. SERVQUAL: a multiple-item scale for measuring consumer perceptions of service quality. J Retail. 1988;64:12-40.

7. Van Campen C, Sixma H, Friele RD, Kerssens JJ, Peters L. Quality of care and patient satisfaction: a review of measuring instruments. Med Care Res Rev. 1995;52:109-33.

8. Youssef FN, Nel D, Bovaird T. Health care quality in NHS hospitals. Int J Health Care Qual Assur. 1996:9:15-28.

9. Mira JJ, Aranaz J, Rodríguez-Marín J, Buil JA, Castell M, Vitaller J. [SERVQHOS: un cuestionario para evaluar la calidad percibida de la asistencia hospitalaria]. Med Prevent. 1998;4:12-8.

10. Numpaque-Pacabaque A, Rocha-Buelvas A. SERVQUAL and SERVQHOS models for the evaluation of quality of health services: a literature review. Rev Fac Med. 2016:64:715-20.

11. Puig A, Pagán JA, Wong R. Assessing quality across health care subsystems in Mexico. J Ambul Care Manage. 2009;32:123-31.

12. Porter ME. A strategy for health care reform: toward a value-based system. N Eng J Med. 2009;361:109-12.

13. Krahn M, Naglie G. The next step in guideline development: incorporating patient preferences. JAMA. 2008;300:436-8.

14. Doubova SV, García-Saisó S, Pérez-Cuevas R, Sarabia-González $O$ Pacheco-Estrello P, Leslie $\mathrm{HH}$, et al. Barriers and opportunities to improve the foundations for high-quality healthcare in the Mexican health system. Health Policy Plan. 2018;33:1073-82.

15. Williams G, Pattison G, Mariathas C, Lazar J, Rashied M. Improving parental satisfaction in pediatric orthopaedics. J Pediatr Orthop. 2011;31:610-5

16. Matziou V, Boutopoulou B, Chrysostomou A, Vlanchioti E, Mantziou T, Petsios K. Parents' satisfaction concerning their child's hospital care. Jpn J Nurs Sci. 2011;8:163-73.

17. Tsironi S, Koulierakis G. Factors affecting parents' satisfaction with pediatric wards. Jpn J Nurs Sci. 2019;16:212-20.

18. Spahr CD, Flugstad NA, Brousseau DC. The impact of a brief expectation survey on parental satisfaction in the pediatric emergency department. Acad Emerg Med. 2006;13:1280-7.

19. Latour JM, van Goudoever JB, Duivenvoorden HJ, van Dam NA, Dullaart $\mathrm{E}$, Albers MJ, et al. Perceptions of parents on satisfaction with care in the pediatric intensive care unit: the EMPATHIC study. Intensive Care Med. 2009;35:1082-9.

20. Tsironi S, Bovaretos N, Tsoumakas K, Giannakopoulou M, Matziou V. Factors affecting parental satisfaction in the neonatal intensive care unit. J Neonat Nurs. 2012;18:183-92.

21. Hong SS, Murphy SO, Conolly PM. Parental satisfaction with nurses' communication and pain management in a pediatric unit. Pediatr Nurs. 2008;34:289-93

22. Power N, Franck L. Parent participation in the care of hospitalized children: a systematic review. J Adv Nurs. 2008;62:622-41.

23. Arrébola-Pajares A, Tejido-Sánchez A, Jiménez-Alcaide E, Medina-Polo J, Pérez-Cadavid S, Guerrero-Ramos F, et al. Survey of satisfaction in hospitalized patients at a urology department. Arch Esp Urol. 2014;67:621-7.

24. Gómez Martín C, García Morato RA, de los Reyes Cortés N, Fernández-Cañamaque JL, Holguín P. Patient satisfaction in a Spanish burn unit. Burns. 2019;45:341-7.

25. Pérez Cantó V, Maciá Soler L, González Chordá VM. [User satisfaction in 2 hospitals with different management models]. J Healthc Qual Res. 2018;33:334-42

26. Ygge BM, Arnetz JE. Quality of pediatric care: application and validation of an instrument for measuring parent satisfaction with hospital care. Int J Qual Health Care. 2001;13:33-43.

27. Khan A, Furtak SL, Melvin P, Rogers JE, Schuster MA, Landrigan CP. Parent-provider miscommunications in hospitalized children. Hosp Pediatr. 2017;7:505-15.

28. Tolosa D, Leguizamón J, Dávila F. [Quality of communication with the caregiver of pediatric patient]. J Healthc Qual Res. 2018;33:264-9.

29. Reader TW, Gillespie A, Roberts J. Patient complaints in health care systems: a systematic review and coding taxonomy. BMJ Qual Saf. 2014;23:678-89.

30. Harrison R, Walton M, Healy J, Smith-Merry J, Hobbs C. Patient complaints about hospital services: applying a complaint taxonomy to analyse and respond to complaints. Int J Qual Health Care. 2016;28:240-5. 